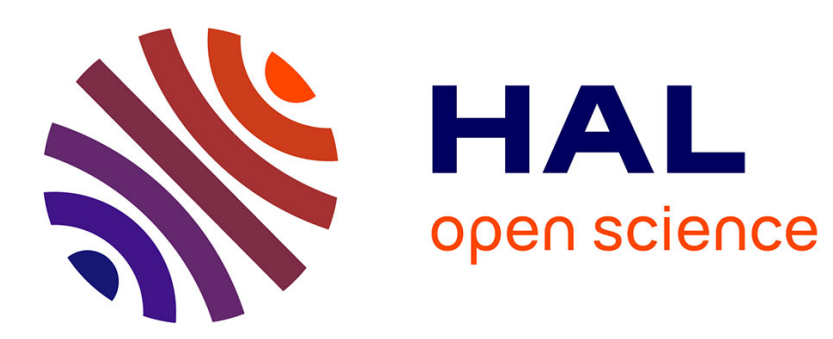

\title{
Erratum: A simple hypothesis for the spin glass phase of the infinite-ranged SK model
}

\author{
G. Parisi, G. Toulouse
}

\section{To cite this version:}

G. Parisi, G. Toulouse. Erratum: A simple hypothesis for the spin glass phase of the infinite-ranged SK model. Journal de Physique Lettres, 1981, 42 (3), pp.71-71. 10.1051/jphyslet:0198100420307100 . jpa-00231876

\section{HAL Id: jpa-00231876 https://hal.science/jpa-00231876}

Submitted on 1 Jan 1981

HAL is a multi-disciplinary open access archive for the deposit and dissemination of scientific research documents, whether they are published or not. The documents may come from teaching and research institutions in France or abroad, or from public or private research centers.
L'archive ouverte pluridisciplinaire HAL, est destinée au dépôt et à la diffusion de documents scientifiques de niveau recherche, publiés ou non, émanant des établissements d'enseignement et de recherche français ou étrangers, des laboratoires publics ou privés. 


\section{Erratum}

A simple hypothesis for the spin glass phase of the infinite-ranged SK model

G. Parisi and G. Toulouse

(J. Physique Lett. 41 (1980) L-361).

There was an inconsistency, pointed out by Marc Gabay, in some highest order terms, as computed by one of us (G.T.). The corrected formulae are :

$$
\begin{aligned}
H^{2} & \simeq \frac{4}{3} \tau^{3}(1+\tau) \\
M & \simeq \cdots+\frac{7}{6} H^{3}
\end{aligned}
$$

$$
\begin{aligned}
\chi(H) & \simeq \cdots+\frac{7}{2} H^{2} \\
H^{2} & =\frac{4}{3} \tau^{3}+\mathrm{O}\left(\tau^{5}\right) \\
\Delta \chi & \simeq \frac{1}{3} H^{2} .
\end{aligned}
$$

This does not bring any modification to the physical conclusions of the letter. 